NBER WORKING PAPER SERIES

\title{
COLLATERAL DAMAGE
}

Gary B. Gorton

Toomas Laarits

Working Paper 24298

http://www.nber.org/papers/w24298

\author{
NATIONAL BUREAU OF ECONOMIC RESEARCH \\ 1050 Massachusetts Avenue \\ Cambridge, MA 02138 \\ February 2018
}

Prepared for the Banque de France Financial Stability Review. The views expressed herein are those of the authors and do not necessarily reflect the views of the National Bureau of Economic Research.

NBER working papers are circulated for discussion and comment purposes. They have not been peer-reviewed or been subject to the review by the NBER Board of Directors that accompanies official NBER publications.

(C) 2018 by Gary B. Gorton and Toomas Laarits. All rights reserved. Short sections of text, not to exceed two paragraphs, may be quoted without explicit permission provided that full credit, including $(\odot$ notice, is given to the source. 
Collateral Damage

Gary B. Gorton and Toomas Laarits

NBER Working Paper No. 24298

February 2018

JEL No. E4,E44,E58,G21

\section{ABSTRACT}

A financial crisis is an event in which the holders of short-term debt come to question the collateral backing that debt. So, the resiliency of the financial system depends on the quality of that collateral. We show that there is a shortage of high-quality collateral by examining the convenience yield on short-term debt, which summarizes the supply and demand for short-term safe debt, taking into account the availability of high-quality collateral. We then show how the private sector has responded by issuing more (unsecured) commercial paper at shorter maturities. The results suggest that there is a shortage of safe debt now compared to the pre-crisis period, implying that the seeds for a new shadow banking system to grow exist.

Gary B. Gorton

Yale School of Management

135 Prospect Street

P.O. Box 208200

New Haven, CT 06520-8200

and NBER

Gary.Gorton@yale.edu

Toomas Laarits

Yale School of Management

135 Prospect Street

P.O. Box 208200

New Haven, CT 06520-8200

toomas.laarits@yale.edu 


\section{Introduction}

In a classic banking panic, holders of demand deposits want their cash back because they do not trust the value of the banks' loan portfolios backing the deposits. Deposit insurance solves this problem. In the crisis of 2007-8 the holders of short-term debt, in the form of repo, came to distrust the bonds used as collateral and increased haircuts, generating a run on the banking system. ${ }^{1}$ Have the many post-crisis legal and regulatory changes to banking systems mitigated this problem? Or, have these changes exacerbated the shortage of good collateral, resulting in collateral damage? To the extent new laws and regulations constrain private short-term debt issuance, they also create an incentive to find new ways to produce private debt - a new shadow banking system. We seek to study this incentive for private safe debt production by looking at the relative change in the convenience yield on short-term debt, and the private sector response to increases in the convenience yield.

Short-term money-like debt is always backed by long-term debt as collateral. ${ }^{2}$ So, we can summarize the state of supply and demand of long-term debt collateral indirectly by looking at the convenience yield on short-term debt. The convenience yield summarizes the outcome of the plethora of legal and regulatory changes post-crisis. Our results show that measures of the convenience yield have not returned to pre-crisis levels. Further, we find that the quantity and maturity of private issuance of short-term debt claims is sensitive to high-frequency changes in Treasury supply, more so than in the pre-crisis period. Overall, the results suggest a shortage of high-quality collateral.

In the last forty years the financial system permanently changed from a system that mostly produced retail (insured) demand deposits to a system that produces significant amounts of short-term (uninsured) debt for the wholesale market. This new system produces short-term debt to a large extent with backing collateral produced from the very loans that the traditional banking system originates, a process called securitization. The transformation of the financial system is dramatic. Using U.S. Flow of Funds (now called the Financial Accounts of the U.S.) data, Gorton et al. (2012) analyze the transformation of the U.S. banking system over the period 1952Q1 through 2009Q1. As a percentage of the total amount of privately-produced safe debt, demand deposits fell from about $80 \%$ to $31 \%$. Money-like debt (e.g., repo, commercial paper, money market funds) rose from $11 \%$ to $21 \%$. AAA asset-backed and mortgage-backed securities rose from zero to $18 \%$. The shadow banking system is the sum of the ABS/MBS and money-like debt components, which increased from $11 \%$ to $38 \%$, overtaking demand deposits in total value. This transformation seems to have accelerated in the late $1980 \mathrm{~s}$, and it is apparent that the change is not temporary.

Has the shadow banking system become safer post-crisis? It is hard to answer this question because there have been so many changes since the financial crisis, including the introduction of many new bank regulations and capital requirements. Also, since the crisis, the production of privatelyproduced collateral in the form of AAA securitization tranches has declined. The sovereign debt of some countries is no longer considered safe. ${ }^{3}$ There was a large amount of net government debt issuance during the crisis, but central bank quantitative easing programs absorbed considerable amounts of government debt and other high quality collateral. And recent bank regulations, for example the liquidity coverage ratio, have aimed at tying up high quality collateral, making it

\footnotetext{
${ }^{1}$ See Gorton and Metrick (2012) and Gorton et al. (2017).

${ }^{2}$ See Dang et al. (2012).

${ }^{3}$ On the global reduction in safe assets since the crisis see Barclays Capital (2012).
} 
immobile. ${ }^{4}$ What has been the net effect of all these changes? Answering this question is essential for understanding the post-crisis financial system. We argue that the convenience yield can serve as a valuable statistic summarizing the effects of these changes. A high convenience yield corresponds to a relative scarcity of short-term safe debt, suggesting an insufficient amount of collateral to back short-term debt.

Dang et al. (2012) argue that information-insensitivity is the defining feature of "safe" debt. Maximal information-insensitivity is achieved by debt-on-debt, debt backed by debt. If there is a shortage of collateral to back the debt, the private sector can respond by issuing unsecured short-term debt (backed by a portfolio of debt, bonds or loans), attempting to make it information-insensitive by shortening maturities. With an insufficient amount of bonds to back repo the private sector will produce short-term debt elsewhere. We show a correlation between the issuance of (unsecured) commercial paper and heightened convenience yields and that the maturity of the commercial paper has shortened. This has persisted since the crisis.

In Section 1 we examine the levels of various measures of the convenience yield, comparing the current levels to pre-crisis values. In Section 2 we look at the sensitivity of the convenience yield to exogenous (but anticipated) shocks to the amount of outstanding U.S. Treasury bills. In Section 3 we examine how the sensitivity of issuance and maturity of financial commercial paper have changed, compared to the pre-crisis period. Section 4 concludes by briefly discussing what the results mean.

\section{Levels}

We begin by examining changes in the levels of various measures of the convenience yield on long and short-term debt. These measures are the one and three month spread between the general collateral (GC) repo rate and the U.S. Treasury bill rate, the spread between AAA corporates and U.S. Treasury bonds, and the spread between Baa and U.S. Treasury bonds. Krishnamurthy and VissingJorgensen (2014) and Krishnamurthy and Vissing-Jorgensen (2015) examine such convenience yield measures and associate them with the outstanding aggregate supply of Treasuries. Another measure of the convenience yield can be constructed by comparing market rates with rates from a fitted yield curve, like in Greenwood et al. (2015). We construct a version of their "z-spread" - the average spread between T-bills with remaining maturities between 4 to 26 weeks and fitted values from Gürkaynak et al. (2012). We subtract market rates from fitted rates to ensure a positive z-spread, on average. As Figure 1 shows, this measure is strongly correlated with the GC-1 month Treasury spread.

We want to see if these measures of the convenience yields marginally increased during the crisis and again in the post-crisis period, compared to the pre-crisis baseline. To do this we run a simple regression with a constant (the baseline), a dummy variable that is turned to one starting in July 2007 (the start of the crisis) and another dummy that is turned to one from 2012 to the present. The coefficient on the first dummy tells us how the convenience yield level changed during the crisis compared to the baseline. The coefficient on the second dummy tells us how the convenience yield has changed since the crisis. We also report the p-value for the sum of the coefficients on the crisis and post-crisis dummies being different from zero. If the coefficients sum to zero, then the current

\footnotetext{
${ }^{4}$ See Gorton and Muir (2016).
} 
period is like the pre-crisis period.

Table 1 shows the results. The first row of the table shows that convenience yields rose during the crisis, consistent with a shortage of safe short-term debt. The second row shows that since then convenience yields have come down. But, adding these two coefficients shows that overall convenience yields have not returned to pre-crisis levels - the sum of the two dummies is positive in all cases. The p-values show that the hypothesis that the crisis plus post-crisis dummies sum to zero is strongly rejected in all cases.

\begin{tabular}{lccccc}
\hline & GC-Tr 1m & GC-Tr 3m & Z-spread & Aaa-Tr & Baa-Tr \\
\hline $\mathbb{I}($ July 2007-present) & $0.135^{* * *}$ & $0.131^{* * *}$ & $0.0987^{* * *}$ & $0.425^{* * *}$ & $0.885^{* * *}$ \\
& $(17.13)$ & $(19.43)$ & $(20.61)$ & $(26.91)$ & $(32.39)$ \\
$\mathbb{I}(2012$-present) & $-0.0958^{* * *}$ & $-0.0654^{* * *}$ & $-0.0260^{* * *}$ & -0.0204 & $-0.432^{* * *}$ \\
& $(-11.74)$ & $(-9.15)$ & $(-5.14)$ & $(-1.21)$ & $(-14.79)$ \\
Constant & $0.109^{* * *}$ & $0.0596^{* * *}$ & $0.0749^{* * *}$ & $1.391^{* * *}$ & $2.348^{* * *}$ \\
& $(21.07)$ & $(13.79)$ & $(24.40)$ & $(137.60)$ & $(134.30)$ \\
\hline p (crisis+post $\neq 0)$ & $<0.001$ & $<0.001$ & $<0.001$ & $<0.001$ & $<0.001$ \\
Observations & 3840 & 3985 & 3983 & 3931 & 3931 \\
$R^{2}$ & 0.0728 & 0.0874 & 0.108 & 0.202 & 0.213 \\
\hline$t$ statistics in parentheses & & & & \\
${ }^{*} p<0.10,{ }^{* *} p<0.05,{ }^{* * *} p<0.01$ & & & &
\end{tabular}

Table 1: Proxies of the Convenience Yield. Daily sample from January 2001 to December 2016. Source: General Collateral repo rates from Bloomberg. "z-spread" from authors' calculations, following Greenwood et al. (2015). AAA and Treasury interest rates from Federal Reserve H.15 release.

Figure 1 below plots three measures of the convenience yield. 


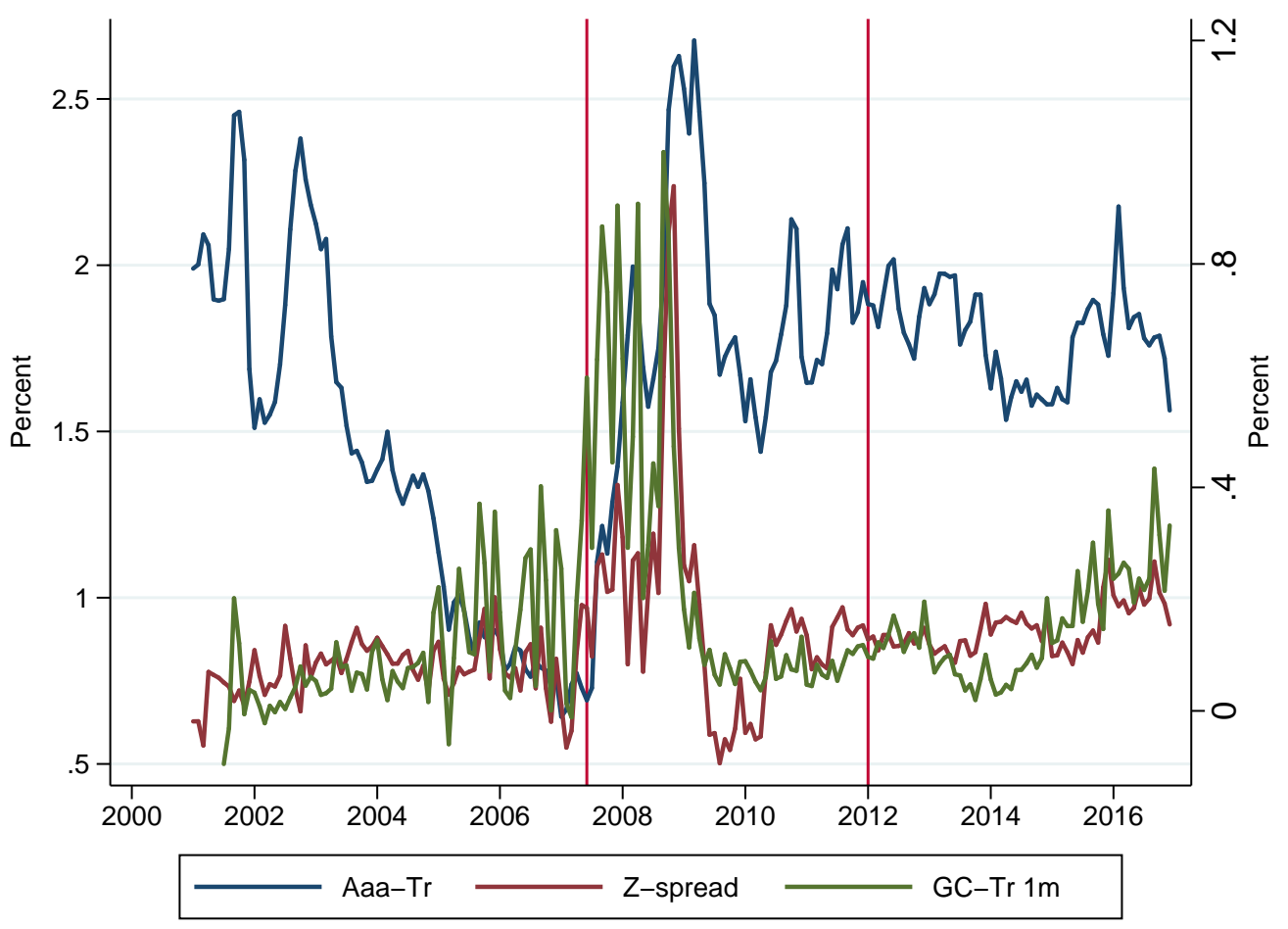

Figure 1: Proxies of the Convenience Yield. Monthly averages from January 2001 to December 2016. Vertical lines depict the dummy variable cutoff dates. GC-Tr 1m spread and z-spread on right axis. Source: General Collateral repo rates from Bloomberg. "z-spread" from authors' calculations, following Greenwood et al. (2015). AAA and Treasury interest rates from Federal Reserve H.15 release. 


\section{Tax Day Dynamics}

Another way to gauge the scarcity of short-term safe debt is to look at the sensitivity of U.S. Treasury yields and convenience yields to Treasury bill (anticipated) supply shocks. In this section we study the sensitivity of convenience yields to a supply shock which occurs annually around April 15 in the U.S., when households and firms pay their taxes. Anticipating an inflow of cash, the Treasury issues fewer Treasury bills. When there is a decline in the outstanding supply of bills, how does the yield on bills and the convenience yield change?

The regressions reported in Table 2 regress changes in yields on contemporaneous supply changes in Treasury bills. We further interact the right-hand-side variables with the two dummy variablescrisis and post-crisis - used in Section 1. We examine daily data in a ten day window around the tax day.

The baseline regression shows that when the supply of Treasuries drops, the yield on the one month Treasury goes down, corresponding to an increase in the price of bills. The coefficient 0.58 in the first column implies that a $5 \%$ drop in T-bill supply corresponds to a 2.9 basis point decrease in the 1 month yield. During the crisis, and since 2008, the yields went up more, for a given size of supply shock. And, since 2012 there was a reduction in the sensitivity to supply shocks, but overall the response to the tax-related decrease remains heightened. However, the p-value on the sum of the coefficients cannot reject that the sum is zero.

Table 2 also shows the response of the GC repo-one month Treasury ( $\operatorname{Tr} 1 \mathrm{~m}$ ) bill spread. A negative shock to Treasuries outstanding causes the spread to increase, more so with the onset of the crisis. In the baseline, a $5 \%$ drop in T-bill supply corresponds to 3 basis point increase in the GC-Tr $1 \mathrm{~m}$ spread. Since the crisis the sensitivity to bill supply has decreased and the overall effect is not different from the pre-crisis period at the usual $5 \%$ significance level.

Figure 2 displays these results graphically. Here we plot of T-bill supply, T-bill rates, and the GC repo-Treasury Bill spread (as deviations from their 60-day means) five days before and after the tax day on April 15. The top panel shows the data for the 2002-2017 sample; the bottom panel

shows the data for 2009-2017. As the outstanding T-bill supply falls, the Treasury yield goes down and the convenience yield rises.

The evidence from studying the tax day dynamics is mixed, but suggestive and consistent with our other evidence. 


\begin{tabular}{|c|c|c|c|c|c|c|}
\hline \multirow[b]{2}{*}{$\Delta$ Bills Supply } & \multicolumn{3}{|c|}{ Tr 1m Yield } & \multicolumn{3}{|c|}{ GC-Tr $1 \mathrm{~m}$ Spread } \\
\hline & $\begin{array}{c}0.583^{* *} \\
(2.93)\end{array}$ & $\begin{array}{c}0.368^{* *} \\
(2.83)\end{array}$ & $\begin{array}{c}0.368^{* *} \\
(2.82)\end{array}$ & $\begin{array}{c}-0.612^{* * *} \\
(-4.49)\end{array}$ & $\begin{array}{c}-0.525^{* * *} \\
(-4.57)\end{array}$ & $\begin{array}{r}-0.525^{* * *} \\
(-4.56)\end{array}$ \\
\hline$\Delta$ Supply X II(2008-present) & & $\begin{array}{c}0.817^{* *} \\
(2.86)\end{array}$ & $\begin{array}{c}1.074^{* * *} \\
(6.45)\end{array}$ & & $\begin{array}{l}-0.330 \\
(-1.24)\end{array}$ & $\begin{array}{c}-0.595^{* * *} \\
(-4.27)\end{array}$ \\
\hline$\Delta$ Supply X II(2012-present) & & & $\begin{array}{c}-0.903^{* * *} \\
(-5.01)\end{array}$ & & & $\begin{array}{c}0.930^{* * *} \\
(6.60)\end{array}$ \\
\hline $\mathrm{p}($ crisis + post $\neq 0)$ & & & 0.396 & & & 0.0594 \\
\hline Year FE & $\mathrm{Y}$ & $\mathrm{Y}$ & $\mathrm{Y}$ & $\mathrm{Y}$ & $\mathrm{Y}$ & $\mathrm{Y}$ \\
\hline Observations & 176 & 176 & 176 & 176 & 176 & 176 \\
\hline$R^{2}$ & 0.871 & 0.880 & 0.883 & 0.904 & 0.906 & 0.909 \\
\hline
\end{tabular}

Table 2: Tax Day. Daily data. 5 days before and after Tax Day. Sample from 2002 to 2017. Standard errors clustered by year. Yearly fixed effects. Source: Supply calculated from TreasuryDirect auction schedule. Interest rates from Federal Reserve H.15 release. General Collateral repo rates from Bloomberg. 

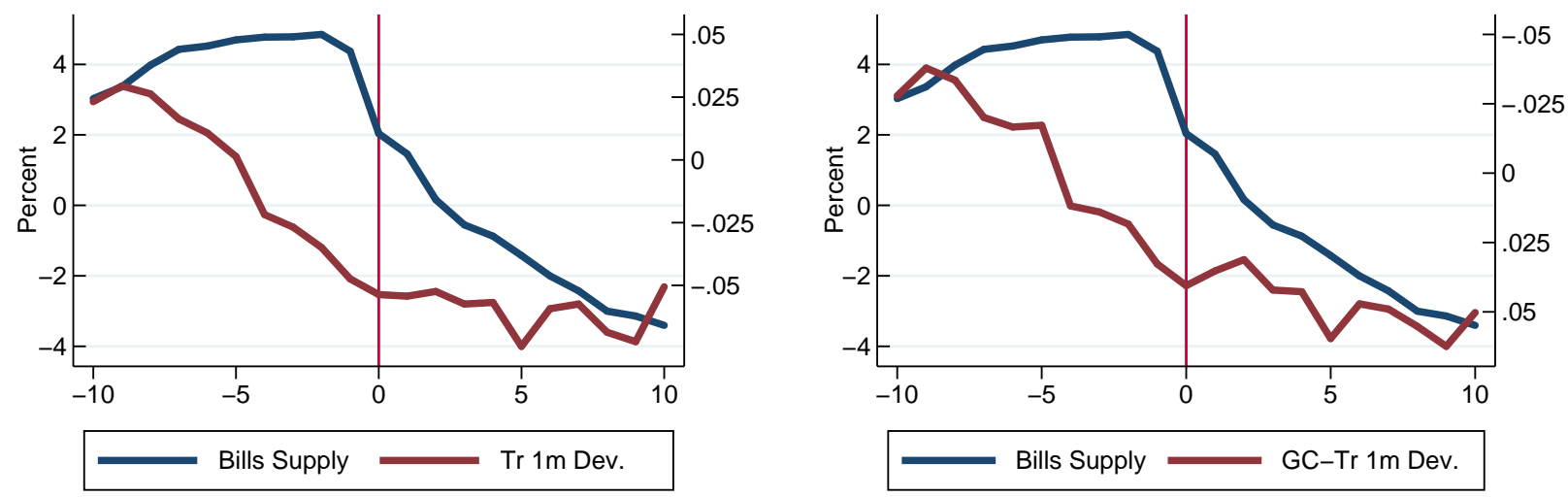

Sample: 2002-2017

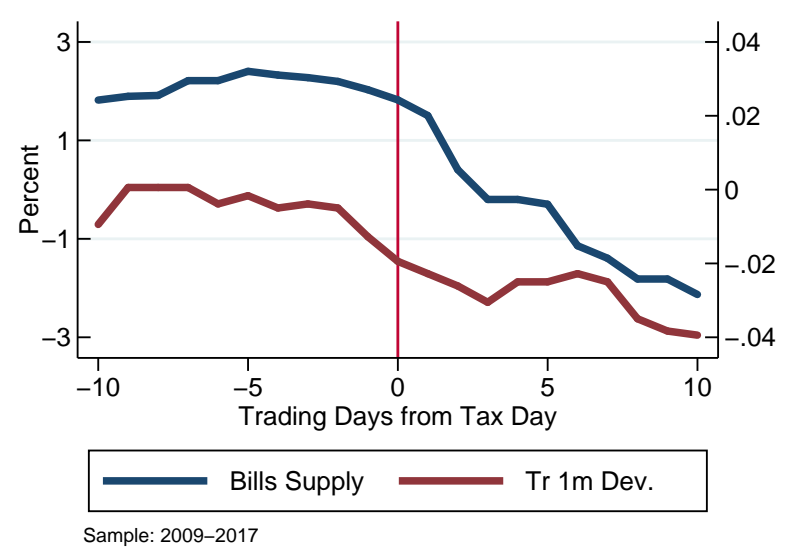

Sample: 2002-2017

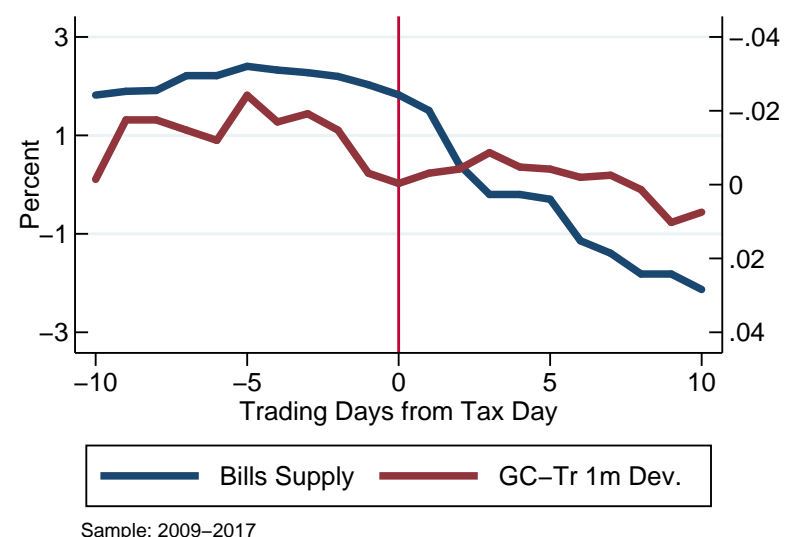

Sample: 2009-2017

Figure 2: Treasury Bills Supply around Tax Day. Treasury Yields, General Collateral (GC) Spread around Tax Day. Supply and yields reported relative to the 60-day mean around tax day. Top row depicts entire 2002-2017 sample. Bottom row depicts 2009-2017 sample. Supply shock on left axis, yield deviation on right axis. Right axis inverted for graphs with GC-Tr spread. Source: Supply calculated from TreasuryDirect auction schedule. Interest rates from Federal Reserve H.15 release. General Collateral repo rates from Bloomberg. 


\section{Commercial Paper Issuance and Maturity}

Still another way to look at the issue of whether there is a relative scarcity of money-like debt is by examining private sector net issuance of short-term debt in response to changes in Treasury bill supply or the convenience yield, like in Sunderam (2014). Specifically, we study the change in outstanding financial commercial paper as a function of Treasury supply, and as a function of the GC-Treasury 1m spread. Commercial paper issued by financial firms is another kind of shortterm debt (though unsecured), with the preponderance of the paper issued at short maturities (in 2017, maturities of 1-4 days made up 58\% of issuance). An issuer seeking to issue a maximally information insensitive asset would tilt towards shorter maturities.

Table 3 shows that reductions in the Treasury bills outstanding, normalized by GDP, coincide with increases in net $(\log )$ issuance of the privately-produced substitutes. In the baseline case, a $1 \%$ reduction in Bills/GDP coincides with a $0.33 \%$ increase in financial commercial paper outstanding. The interaction terms with dummy variables for crisis and post-crisis periods demonstrate that this sensitivity is mostly on account of the post-crisis period. We strongly reject the null hypothesis that crisis plus post-crisis interaction terms sum to zero.

\begin{tabular}{|c|c|c|c|c|}
\hline \multirow[b]{2}{*}{$\Delta$ Bills/GDP } & \multicolumn{4}{|c|}{$\Delta$ Financial Commercial Paper Outstanding } \\
\hline & $\begin{array}{c}-0.331^{* * *} \\
(-3.38)\end{array}$ & $\begin{array}{c}-0.0238 \\
(-0.13)\end{array}$ & $\begin{array}{l}-0.162 \\
(-1.39)\end{array}$ & $\begin{array}{c}-0.0238 \\
(-0.13)\end{array}$ \\
\hline$\Delta$ Bills X I(July 2007-present) & & $\begin{array}{c}-0.433^{* *} \\
(-2.01)\end{array}$ & & $\begin{array}{l}-0.236 \\
(-0.99)\end{array}$ \\
\hline $\mathbb{I}($ July 2007-present) & & $\begin{array}{c}-0.00208 \\
(-0.94)\end{array}$ & & $\begin{array}{c}-0.00399 \\
(-1.45)\end{array}$ \\
\hline$\Delta$ Bills X II(2012-present) & & & $\begin{array}{c}-0.560^{* * *} \\
(-2.63)\end{array}$ & $\begin{array}{c}-0.463^{* *} \\
(-1.97)\end{array}$ \\
\hline $\mathbb{I}(2012$-present $)$ & & & $\begin{array}{c}0.000938 \\
(0.40)\end{array}$ & $\begin{array}{c}0.00345 \\
(1.18)\end{array}$ \\
\hline Constant & $\begin{array}{c}-0.00115 \\
(-1.04)\end{array}$ & $\begin{array}{c}0.0000352 \\
\quad(0.02)\end{array}$ & $\begin{array}{c}-0.00144 \\
(-1.09)\end{array}$ & $\begin{array}{c}0.0000352 \\
\quad(0.02)\end{array}$ \\
\hline $\mathrm{p}($ crisis + post $\neq 0)$ & & & & 0.00609 \\
\hline Observations & 819 & 819 & 819 & 819 \\
\hline$R^{2}$ & 0.0138 & 0.0197 & 0.0223 & 0.0260 \\
\hline
\end{tabular}

Table 3: Commercial Paper Issuance and Treasury Bills Outstanding. Weekly regressions 2/2001-12/2017. Source: CP outstanding and GDP from Federal Reserve Bank of St. Louis FRED database. Bills outstanding from CRSP.

We also examine how the outstanding amount of financial commercial paper is related to a measure of the convenience yield, the GC-Treasury one month spread. The results in Table 4 demonstrate 
that an increase in the convenience yield is associated with an increase in the (log of) outstanding amount of financial commercial paper. Like before, we find that the sensitivity has increased since the crisis. The interaction term with the post-crisis dummy indicates that a 1 basis point increase in the GC-Tr $1 \mathrm{~m}$ spread coincides with a $0.10 \%$ increase in financial paper outstanding.

\begin{tabular}{|c|c|c|c|c|}
\hline \multirow[b]{2}{*}{$\Delta \mathrm{GC}-\operatorname{Tr} 1 \mathrm{~m}$} & \multicolumn{4}{|c|}{$\Delta$ Financial Commercial Paper Outstanding } \\
\hline & $\begin{array}{c}-0.00443 \\
(-0.45)\end{array}$ & $\begin{array}{c}-0.0138 \\
(-0.97)\end{array}$ & $\begin{array}{c}-0.0118 \\
(-1.17)\end{array}$ & $\begin{array}{c}-0.0138 \\
(-0.97)\end{array}$ \\
\hline$\Delta$ GC-Tr 1m X I(July 2007-present) & & $\begin{array}{c}0.0174 \\
(0.89)\end{array}$ & & $\begin{array}{c}0.00336 \\
(0.17)\end{array}$ \\
\hline $\mathbb{I}($ July 2007-present) & & $\begin{array}{c}-0.00240 \\
(-1.06)\end{array}$ & & $\begin{array}{c}-0.00457 \\
(-1.62)\end{array}$ \\
\hline$\Delta$ GC-Tr $1 \mathrm{~m} X \mathbb{I}(2012$-present $)$ & & & $\begin{array}{c}0.105^{* * *} \\
(2.77)\end{array}$ & $\begin{array}{c}0.104^{* * *} \\
(2.64)\end{array}$ \\
\hline $\mathbb{I}(2012$-present $)$ & & & $\begin{array}{c}0.000782 \\
(0.34)\end{array}$ & $\begin{array}{c}0.00357 \\
(1.25)\end{array}$ \\
\hline Constant & $\begin{array}{c}-0.000913 \\
(-0.83)\end{array}$ & $\begin{array}{c}0.000562 \\
(0.32)\end{array}$ & $\begin{array}{c}-0.00122 \\
(-0.88)\end{array}$ & $\begin{array}{c}0.000562 \\
\quad(0.32)\end{array}$ \\
\hline $\mathrm{p}($ crisis + post $\neq 0)$ & & & & 0.00653 \\
\hline Observations & 841 & 841 & 841 & 841 \\
\hline$R^{2}$ & 0.000245 & 0.00251 & 0.00947 & 0.0126 \\
\hline
\end{tabular}

Table 4: Commercial Paper Issuance and GC-Treasury Spread. Weekly regressions 2/2001-12/2017. Source: CP outstanding from Federal Reserve Bank of St. Louis FRED database. $G C$ repo rate from Bloomberg.

Finally, we find a reduction in average maturities of commercial paper, consistent with the view that these claims are issued in part to counteract variation in Treasury bills supply and that informationinsensitivity can be recovered by shortening maturity. As shown in the first three columns of Table 5 , on aggregate, commercial paper maturities shortened during the crisis, and have stayed at those levels.

What is more, we find that average maturities decrease when Treasury supply is low, or when the GC-1m Treasury spread is high. We find that a 10 basis point increase in the GC-Tr $1 \mathrm{~m}$ spread coincides with a $1.2 \%$ increase in the share of short maturity commercial paper; a $1 \%$ increase in Bills/GDP coincides with a $0.91 \%$ decrease in short maturity commercial paper. In both cases, we reject the null hypothesis that the crisis and post-crisis interaction terms sum to zero. 


\begin{tabular}{|c|c|c|c|c|c|}
\hline & \multicolumn{3}{|c|}{ Share Short CP } & \multicolumn{2}{|c|}{$\Delta$ Share Short CP } \\
\hline $\mathbb{I}$ (July 2007-present) & & $\begin{array}{c}5.565^{* * *} \\
(17.23)\end{array}$ & $\begin{array}{c}5.280^{* * *} \\
(13.45)\end{array}$ & $\begin{array}{c}0.0396 \\
(0.11)\end{array}$ & $\begin{array}{c}0.0388 \\
(0.12)\end{array}$ \\
\hline $\mathbb{I}(2012$-present $)$ & & & $\begin{array}{c}0.501 \\
(1.28)\end{array}$ & $\begin{array}{c}-0.0790 \\
(-0.22)\end{array}$ & $\begin{array}{c}-0.0795 \\
(-0.23)\end{array}$ \\
\hline$\Delta \mathrm{GC}-\operatorname{Tr} 1 \mathrm{~m}$ & & & & $\begin{array}{l}1.869 \\
(0.61)\end{array}$ & \\
\hline$\Delta$ GC-Tr 1m X I(July 2007-present) & & & & $\begin{array}{l}1.552 \\
(0.45)\end{array}$ & \\
\hline$\Delta$ GC-Tr 1m X II(2012-present) & & & & $\begin{array}{c}12.24^{* *} \\
(2.02)\end{array}$ & \\
\hline$\Delta$ Bills/GDP & & & & & $\begin{array}{c}-95.20^{* * *} \\
(-3.22)\end{array}$ \\
\hline$\Delta$ Bills X II(July 2007-present) & & & & & $\begin{array}{l}-36.24 \\
(-0.96)\end{array}$ \\
\hline$\Delta$ Bills X I(2012-present) & & & & & $\begin{array}{c}-90.60^{* *} \\
(-2.54)\end{array}$ \\
\hline Constant & $\begin{array}{l}72.08^{* * *} \\
(399.54)\end{array}$ & $\begin{array}{l}68.53^{* * *} \\
(265.61)\end{array}$ & $\begin{array}{l}68.53^{* * *} \\
(265.71)\end{array}$ & $\begin{array}{c}0.00172 \\
(0.01)\end{array}$ & $\begin{array}{c}0.00548 \\
(0.02)\end{array}$ \\
\hline $\mathrm{p}($ crisis + post $\neq 0)$ & & & $<0.001$ & 0.0371 & 0.00153 \\
\hline Observations & 843 & 843 & 843 & 842 & 794 \\
\hline$R^{2}$ & 0 & 0.261 & 0.262 & 0.0141 & 0.123 \\
\hline
\end{tabular}

$t$ statistics in parentheses

${ }^{*} p<0.10,{ }^{* *} p<0.05,{ }^{* * *} p<0.01$

Table 5: Commercial Paper Maturity. Change in Commercial Paper Maturity. Share of commercial paper with maturity under 10 days over total commercial paper, in percent. Weekly regressions 1/2002-12/2017. Source: CP maturity and GDP from Federal Reserve Bank of St. Louis FRED database. GC repo rate from Bloomberg. Bills outstanding from CRSP. 


\section{Conclusion}

Since the financial crisis there has been an enormous amount of legal and regulatory changes with regard to banks. There has been new bank legislation in many countries and new bank regulations. Central banks have purchased large amounts of safe debt. Some sovereign debt is no longer considered safe. Regulatory requirements have rendered large swaths of good collateral immobile, for example, the liquidity coverage ratio. What is the effect of all these changes - is the financial system safer? This is an important question. It is hard enough to evaluate individual policy and legal changes, much less the aggregate of the changes. The Lucas Critique suggests that there may have been unintended consequences.

In this paper we have tried to get at this question by looking at convenience yields, both in levels and in the responsiveness to Treasury supply shocks. Convenience yields summarize the scarcity of safe debt, short-term and by implication long-term safe debt. In general, we find evidence that shortages of short and long-term debt are higher now than pre-crisis. We also find suggestive evidence of a private response in the form of short maturity commercial paper issuance when convenience yields are high, or when Treasury supply is low. Overall, the preponderance of our results suggest that there is a shortage of safe debt now compared to the pre-crisis period, implying that the seeds for a new shadow banking system to grow exist. 


\section{References}

Barclays Capital (2012), "Equity gilt study", http://topforeignstocks.com/2012/10/09/downloadbarclays-equity-giltstudy-2012.

Dang (T. V.) Gorton (G.) and Holmström (B.) (2012), "Ignorance, debt and financial crises", working paper.

Gorton (G.) Laarits (T.) and Metrick (A.) (2017), "The run on repo and the fed's response", working paper.

Gorton (G.) Lewellen (S.) and Metrick (A.) (2012), "The safe asset share", American Economic Review, Papers and Proceedings 96, pp. 101-106.

Gorton (G.) and Metrick (A.) (2012), "Securitized banking and the run on repo", Journal of Financial Economics 104(3), pp. 425-451.

Gorton (G.) and Muir (T.) (2016), "Mobile collateral versus immobile collateral", National Bureau of Economic Research working paper.

Greenwood (R.) Hanson (S. G.) and Stein (J. C.) (2015), "A comparative-advantage approach to government debt maturity", The Journal of Finance 70(4), pp. 1683-1722.

Gürkaynak (R. S.) Sack (B.) and Wright (J. H.) (2012), "The us treasury yield curve: 1961 to the present", Journal of Monetary Economics 54(8), pp. 233-267.

Krishnamurthy (A.) and Vissing-Jorgensen (A.) (2014), "The aggregate demand for treasury debt", Journal of Political Economy 120(2), pp. 939-977.

Krishnamurthy (A.) and Vissing-Jorgensen (A.) (2015), "Short term debt and financial crises: What we can learn from u.s. treasury supply?", working paper.

Sunderam (A.) (2014), "Money creation and the shadow banking system", The Review of Financial Studies 28(4), pp. 939-977. 